\title{
PENINGKATAN KONSEP DIRI MAHASISWI MELALUI KOMUNIKASI INTERPERSONAL PEMBIMBING AKADEMIK
}

\section{Hijrayanti Sari}

Sekolah Tinggi Ilmu Islam dan Bahasa Arab (STIBA) Makassar,

Jl. Inspeksi PAM Manggala-Antang Makassar

E-Mail : hijrahmuin@gmail.com

\begin{tabular}{|c|c|c|}
\hline Keywords : & & $\overline{A B S T R A C T}$ \\
\hline $\begin{array}{l}\text { konsep diri, } \\
\text { interpersonal }\end{array}$ & komunikasi & $\begin{array}{l}\text { The advanced transformation of the era and technology gives influence } \\
\text { to human personality today. Specifically to the students which are still } \\
\text { in the process of personality development. By the advanced } \\
\text { transformation, the competitive environment causes confusion and } \\
\text { future disorientation to the students with their surroundings. Any } \\
\text { behavior is influenced by the self-concept. The self concept is formed } \\
\text { through the environment either it is the family, friends, books, or other } \\
\text { things seen and listened. The objective of the study is to explain the } \\
\text { improvement of the students' self-concept through the interpersonal } \\
\text { effective communicative approach via the supervisors. }\end{array}$ \\
\hline
\end{tabular}




\section{PENDAHULUAN}

Komunikasi adalah kebutuhan setiap manusia. Kebutuhan ini menjadi kebutuhan primer karena manusia adalah mahluk sosial. Setiap harinya manusia melakukan aktifitas komunikasi minimal satu jenis komunikasi baik komunikasi intrapersonal, komunikasi interpersonal, komunikasi lintas budaya, ataupun komunikasi publik. Profesi pendidik adalah profesi transfer nilai dan ilmu. Tentunya alat transfer tersebut adalah dengan komunikasi. Keberhasilan pendidikan salah satu faktor keberhasilannya adalah komunikasi pendidik kepada anak didiknya.

Pendidikan pada hakikatnya merupakan usaha sadar untuk pengembangan kepribadian yang berlangsung seumur hidup baik di sekolah maupun madrasah. Pendidikan juga bermakna proses membantu individu baik jasmani dan rohani ke arah terbentuknya kepribadian utama (pribadi yang berkualitas). Dalam konteks Islam pendidikan bermakna bimbingan terhadap pertumbuhan rohani dan jasmani menurut ajaran islam dengan hikmah mengarahkan, mengajarkan, melatih, mengasuh, dan mengawasi berlakunya semua ajaran islam (Arifin, 1987). Dari makna ini, pendidikan pada hakikatnya merupakan upaya untuk membentuk manusia yang lebih berkualitas. Kualitas manusia yang dimaksud adalah pribadi yang paripurna, yaitu pribadi yang serasi, selaras, dan seimbang dalam aspek-aspek spritual, moral, sosial, intelektual, fisik dan sebagainya. Pribadi yang bekualitas (paripurna) dalam Islam bisa disebut

\footnotetext{
${ }^{1}$ Tohirin, Bimbingan dan konseling di Sekolah dan Madrasah (Berbasis
}

insan kaffah dan insan kamil, yaitu sosok pribadi yang sehat jasmani dan rohaninya, dapat mengimplementasikan iman, ilmu, dan amal serta zikir dalam kehidupan sehari-hari dalam rangka mencapai kebahagiaan hidup di dunia dan akhirat. $^{1}$

Fungsi pendidikan dalam Islam, dijelaskan dalam Al-Qur'an, Allah Subhanahu Wata'ala berfirman dalam surah Al Baqarah ayat 151, "Sebagaimana kami telah mengutus kepada kamu sekalian seorang rasul diantara kamu yang membacakan ayatayat kami kepadamu, menyucikan mu, mengajarkan al-Kitab, dan al-Hikmah, dan mengajarkan kepadamu yang belum kamu ketahui".

Tujuan dan fungsi pendidikan tetap berlanjut pada saat memasuki jenjang perguruan tinggi atau universitas. Dan perkembangan kepribadian tetap berlangsung selama periode pendidikan ini sehingga menjadi penting untuk civitas academik khususnya pembibing akademik tetap mengembangkan konsep diri anak didik dalam hal ini mahasiswa bimbingannya. Pengembangan kepribadian berarti mengambangkan konsep diri mahasiswa, baik melalui organisasi kemahasiswaan ataupun melalui pendekatan personal. Beberapa penelitian menunjukkan bahwa konsep diri positif memberikan peranan yang signifikan terhadap prestasi belajar, kemampuan manusia dalam menghadapi masalah-masalah dalam kehidupan sehari-hari, serta kedewasaan berfikir dan bertindak. Untuk mencapai fungsi tersebut peranan pembimbing akademik menjadi vital karena pembimbing akademik mempunyai intensitas

Integrasi),(Jakarta:PT RAJAGAFINDO PERSADA), 2011, h. 5. 
komunikasi dengan mahasiswa yang lebih dibandingkan civitas akademik yang lain. Sehingga penting pembimbing akademik menerapkan komunikasi interpersonal yang efektif dalam rangka peningkatan konsep diri mahasiswa.

\section{PEMBAHASAN}

Ralph Larossa dan Donald G Reitzes (1993) mengatakan bahwa interaksi simbolik adalah "pada intinya..sebuah kerangka referensi untuk memahami bagaimana manusia, bersama dengan orang lainnya, menciptakan dunia simbolik dan bagaimana dunia ini, sebaliknya membentuk perilaku manusia.

Manusia bertindak terhadap manusia lainnya berdasarkan makna yang diberikan orang lain kepada mereka. Asumsi ini menjelaskan perilaku sebagai suatu rangkaian pemikiran dan perilaku yang dilakukan secara sadar antara rangsangan dan respons orang berkaitan dengan rangsangan tersebut. Teoritikus simbolik interaksi (SI) seperti Herbert Blummer tertarik dengan makna yang ada di balik perilaku. Makna yang kita berikan pada simbol merupakan produk dari interaksi sosial dan menggambarkan kesepakatan kita untuk menerapkan makna tertentu pada simbol tertentu pula. ${ }^{3}$ Tiga asumsi yang diambil dari karya Herbert Blumer, asumsi-asumsi ini adalah sebagai berikut:

1. Manusia bertindak terhadap manusia lainnya berdasarkan makna yang diberikan orang lain pada mereka. Asumsi ini menjelaskan perilaku sebagai suatu

2 Richard West. Lynn H Turner, Pengantar Teori Komunikasi: Analisis dan Aplikasi, Ed 3., Buku 1., (Jakarta:Penerbit Salemba Humanika, 2007), h. 34-42 rangkaian pemikiran dan perilaku yang dilakukan secara sadar antara rangsangan dan respons orang berkaitan dengan rangsangan tersebut. Makna yang kita berikan pada simbol merupakan produk dari interkasi sosial dan menggambarkan kesepakatan kita untuk menerapkan makna tertentu pada simbol tertentu pula.

2. Makna diciptakan dalam interaksi antarmanusia. Mead menekankan dasar intersubjektif dari makna. Makna dapat ada, menurut Mead, hanya ketika orang-orang memiliki interpretasi yang sama mengenai simbol yang mereka pertukarkan dalam interaksi. Blumer (1969) menjelaskan bahwa terdapat tiga cara untuk emnjelaskan asala sebuah makna. Satu pendekatan mengatakan bahwa makna adalah sesuatu yang bersifat intrisik dari suatu benda. Blumer mengatakan "Jadi, sebuah bangku jelas-jelas merupakan bangku di dalam dirinya...maknanya memancar, dapat dikatakan demikian, dari benda tersebut dan sepertinya tidak ada proses yang terlibat dalam pembentukannya; yang penting adalah untuk mengenal makna yang sudah adalah benda tersebut. Pendekatan kedua dari asal usul makna melihat makna itu "dibawa kemana benda oleh seseorang bagi siapa benda itu bermakna" (Blumer, 1969, hal. 4.). Posisi ini mendukung pemikiran yang terkenal bahwa makna terdapat didalam orang, bukand alam benda. Dalam sudut pandang ini maka dijelaskan dengan mengisolasi

\footnotetext{
${ }^{3}$ Richard West. Lynn H Turner, . h. 34-42
} 
elemen-elemen psikologis di dalam seorang individu yang menghasilkan makna. SI mengambil pendekatan makna yang ketiga sebagai sesuatu yang terjadi di antara orang-orang. Makna adalah "produk sosial" atau ciptaan yang dibentuk dalam dan melalui pendefinisian aktivitas manusia ketika mereka berinteraksi" (Blumer, 1969, 1969, hal. 5).

3. Makna dimodifikasi melalui proses interpretif. Blumer menyatakan bahwa proses interpretif ini memiliki dua langkah. Pertama, para pelaku menentukan bendabenda yang mempunyai makna. Blumer berargumen bahwa bagian dari proses ini berbeda dari pendeatan psikologis dan terdiri atas orang yang terlibat di dalam komunikasi dengan dirinya sendiri. Langkah kedua melibatkan si pelaku untuk memilih, mengecek, dan melakukan transformasi makna di dalam konteks di mana mereka berada. ${ }^{4}$

Berdasarkan teori diatas maka jika dikaitkan dengan fungsi pendidik maka semua interaksi yang diberikan oleh dosen, ataupun pembimbing akademik akan memberikan implikasi pada mahasiswa. Sehingga hal ini menjadi dasar pemikiran penulis untuk mengaitkan komunikasi interpersonal dosen sebagai upaya peningkatan konsep diri mahasiswa. Konsep diri tinggi atau positif menjadi penting bagi mahasiswa karena konsep diri tinggi atau positif akan membantu penerapan nilai dan pengetahuan yang di dapatkan di kelas kuliah.

\footnotetext{
${ }^{4}$ Richard West. Lynn H Turner,. h. 99

5 Samuel Soeistoe, Psikologi Pendidikan (Jakarta: Lembaga Penerbit Fakultas Ekonomi UI, 1982), hal 62
}

\section{Konsep Diri}

Konsep diri dapat diartikan gambaran mental seseorang terhadap dirinya sendri. Dan mengenai defenisi tentang konsep diri ini banyak ilmuwan psikologi yang menuturkan pendapatnya. Samuel Soeitoe dalam bukunya psikologi pendidikan mengatakan bahwa konsep diri adalah serangkaian kesimpulan yang diambil seseorang tentang dirinya sendiri baik secara langsung ataupun tidak langsung. ${ }^{5}$

Konsep diri adalah kumpulan kesimpulan-kesimpulan yang diambil adalah berdasarkan observasi diri sendiri dalam situasi yang berbedabeda. Kesimpulan itu adalah uraian tentang pola tingkah lakunya yang khas, uraian tersebut dapat bersifat obyektif dari orang lain dapat mempunyai gambaran yang berbeda-beda tentang diri seseorang dari pandangan yang bersangkutan terhadap dirinya sendiri. ${ }^{6}$ Konsep diri mempunyai komponen sebagai berikut

1. Diri ideal. Selama hidup kita akan mengalami banyak hal dan berinteraksi dengan banyak orang, kita membaca, melihat semua yang ada di sekeliling kita, ini akhirnya akan membentuk diri yang ideal atau visi dari orang terbaik yang kita inginkan menjadi sepertinya. Seseorang tidak selalu menjadi menjalani hidup seperti standar diri ideal yang selalu ditetapkan, namun sadar ataupun tidak seseorang akan selalu mengarah kesana. Dan pada kenyataannya segala hal yang hal. 63

\footnotetext{
${ }^{6}$ Samuel Soeitoe, Psikologi Pendidikan,.
} 
dilakukan akan selalu membandingkan aktivitas dengan karakter dari diri ideal yang selalu ditetapkan. Bila tidak berhati-hati untuk membentuk atau memilih diri ideal maka secara sadar seseorang akan cenderung menetapkan seseorang untuk menjadi diri ideal. Bila orang yang dipilih menjadi diri ideal ini baik maka tidak akan menjadi masalah karena yang diikuti pasti baik pula. Namun jika yang diikuti mempunyai tabiat yang buruk misalnya penyanyi yang terkenal tapi selalu memakai narkoba akibatnya sesuatu yang disadari atau tidak pasti akan cenderung menerima dan mengikuti nilainilai hidup, prinsip, kebiasaan, gaya dan apa saja yang melekat padanya.

2. Citra diri. Perubahan atau peningkatan konsep diri yang paling cepat akan terjadi bila seseorang mengubah citra dirinya. Bila seseorang melihat dirinya dengan cara yang berbeda maka seseorang tersebut akan bertindak berbeda pula, karena bertindak berbeda maka perasaan akan berbeda dan akan mendapatkan hasil yang berbeda pula. Jadi citra diri adalah cara melihat diri sendiri dan menentukan keberhasilan dimasa sekarang. ${ }^{8}$

${ }^{7}$ Adi W. Gunawan, Genius Learning Strategy. (jakarta: PT Gramedia Pustaka Utama, 2007), hal, 27

${ }^{8}$ Adi W. Gunawan, Genius Learning Strategy., hal, 21-22
3. Harga diri. Harga diri merupakan komponen emosional. Perasaan harga diri tampaknya sangat sedehana menyatakan cesara tidak langsung bahwa individu yang bersangkutan merasakan bahwa ia adalah orang yang berharga, menghargai dirinya sendiri terhadap apa dia sekarang ini, tidak mencela terhadapa apa yang tidak dilakukan, dan tingkatan dimana ia merasa positif terhadap dirinya sendiri. Perasaan yang rendah menyatakan penolakan diri, penghinaan diri, dan evaluasi diri yang negative. ${ }^{9}$

\section{Komunikasi}

Wilbur schramm mengatakan bahwa komunikasi didasarkan atas hubungan antara satu dengan yang lain yang fokus pada informasi yang sama, sangkut paut tersebut berada dalam komunikasi tatap muka (face to face communication). ${ }^{10} \quad$ Komunikasi (communication) adalah proses sosial dimana individu-individu menggunakan simbol-simbol untuk menciptakan dan menginterpretasikan makna dalam lingkungan mereka. ${ }^{11}$

Harold D Lasswel salah seorang peletak dasar ilmu komunikasi lewat ilmu politik menyebut tiga fungsi dasar yang menjadi penyebab, mengapa manusia perlu berkomunikasi:

1. Pertama adalah hasrat manusia untuk mengontrol lingkungannya.

${ }_{9}^{9}$ R.B. Burn, Konsep Diri, Teori Pengukuran, Perkembangan dan Perilaku, alih bahasa: Eddy (Jakarta: Arcan, 1993) hal. 69-70

10 Onong Uchjana Effendy, Kepemimpinan dan komunikasi, (Bandung. CV, Mndar Maju, 1998),h. 59.

${ }^{11}$ Richard West. Lynn H Turner, h. 5 
Melalui komunikasi manusia dapat mengetahui peluang-peluang yang ada untuk dimanfaatkan, dipelihara dan menghindar pada hal-hal yang mengancam alam sekitarnya. Melaui komunikasi manusia dapat mengetahui suatu kejadian atau peristiwa. Bahkan melalui komunikasi manusia dapat mengembangkan

pengetahuannya, yakni belajar dari pengalamannya, maupun melaui informasi yang mereka terima dari lingkungan sekitarnya.

2. Kedua adalah upaya manusia untuk dapat beradaptasi dengan lingkungannya. Proses kelanjutan suatu masyarakat sesungguhnya tergantung bagaimana masyarakat itu bisa beradaptasi dengan lingkungannya. Penyesuaian disini bukan saja terletak pada kemampuan manusia memberi tanggapan terhadap gejala alam seperti banjir, gempa bumi, dan musim yang mempengaruhi perilaku manusia, tetapi juga lingkungan masyarakat seperti ini diperlukan penyesuaian, agar manusia dapat hidup dalam suasana yang harmonis.

3. Ketiga, adalah upaya untuk melakukan transformasi warisan sosialisasi. Suatu masyarakat yang ingin mempertahankan keberadaannya, maka anggota masyarakatnya dituntut untuk melakukan pertukaran nilai, perilaku, dam peranan. Misalnya bagaimana orang tua mengajarkan tatakrama bermasyarakat yang baik kepada anak-anaknya. Bagaimana sekolah difungsikan untuk mendidik warga negara.

12 Hafied Cangara, Pengantar IImu Komunikasi, (edisi revisi; Jakarta: Pt Raja Grafindo Persada), h. 2-3 $\begin{array}{lrr}\text { Bagaimana media massa } & \\ \text { menyalurkan } & \text { hati nurani }\end{array}$ khalayaknya, dan bagaimana pemerinah denan kebijaksanaan yang dibuatnya mengayomi kepentingan anggota masyarakat yang dilayaninya. ${ }^{12}$

Komunikasi antarpribadi merupakan pengiriman pesan dari seseorang dan diterima oleh orang lain dengan efek dan umpan balik yang langsung. Menurut Effendy yang dikutip oleh Alo Liliweri, bahwa komunikasi antarpribadi hakikatnya komunikasi antara seorang komunkator dengan seorang komunikan. Jenis komunikasi tersebut diangap paling efektif untuk mengubah sikap, pendapat, atau perilaku manusia berhubung prosesnya yang dialogis. ${ }^{13}$

Toto hernamo memberikan pendapatnya mengenai tujuan komunikasi antarpribadi yakni:

1. Sebagai sarana pembelajaran, melalui komunikasi antarpribadi kita belajar mengenai yang terjadi di dunia ini. Walaupun sebagian besar informasi tersebut kita dapatkan melalui media massa. Informasi juga kita dapatkan melalui komunikasi antar pribadi.

2. Mengenal diri sendiri dan orang lain. Melalui komunikasi antarpribadi kita dapat mengenal diri kita sendiri. Dengan membicarakan tentang diri sendiri kepada orang lain, kita akan mendapatkan perspektif tentang sikap dan perilaku, persepsi diri kita, sebagian besar merupakan hasil interaksi dengan orang lain.

3. Komunikasi antarpribadi membantu kita membentuk relasi karena kita adalah mahluk sosial maka kebutuhan akan berhubungan

${ }^{13}$ Alo liliweri, Komunikasi Antarpribadi (Bandung:Citra Aditya Bakti, 1997), cet ke 2, h. 12 
dengan orang lain merupakan kebutuhan yang paling besar.

4. Melalui komunikasi antarpribadi kita dapat mempengaruhi individu untuk melakukan sesuatu sesuai dengan yang kita inginkan.

5. Melalui komunikasi antarpribadi kita dapat mengakrabkan diri dengan orang lain. ${ }^{14}$

Menurut Gerald R. Miller dan Amrk Steinberg dikutip oleh M. Budyatna, menjelaskan bahwa dalam komunikasi antarpribadi itu dapat dilakukan dengan tiga tingkatan analisis yang digunakan dalam melakukan prediksi yaitu:

1. Analisis pada tingkat kultural. Menurut Koentjoroningrat, yaitu keseluruhan gagasan dan karya manusia yang dibiasakannya dengan belajar. Beserta keseluruhan dan hasil budi dan karya itu. Pada analisis tingkat cultural ini guna mencapai efek yang diharapkan, komunikator dalam melakukan predisi paling tidak harus mengerti dan memahami culture, terutama yang bersifat immaterial dari pihak yang diajak berkomunikasi. Dalam hal ini komunikator melakukan prediksi berdasarkan kultural yang dianut oleh pelaku komunikasi lainnya.

2. Analisis pada tingkat sosiologis, yaitu komunikator melakukan prediksi mengenai reaksi komunikan terhadap pesan yang ia sampaikan berdasarkan keanggotaan komunikan dalam kelompok sosial tertentu, yang berupa nilai-nilai dan norma kelompok yang dianut oleh pihak lain tersebut dan mempunyai perbedaan dengan kelompok lain.

3. Analisis pada tingkat psikologis, yaitu komunikator melakukan prediksi pada psikologis pada pihak lain yang berkomunikasi, yakni karakteristik khas kepribadian pihak lain. Makin besar para pelaku komunikasi saling mengenal secara individu satu sama lain. Maka komunikasi main bersifat pribadi.

\section{KESIMPULAN}

Komunikasi interpersonal dan konsep diri mempunyai hubungan yang positif. Menjaga dan meningkatkan konsep diri mahasiswa bimbingan adalah tanggung jawab pembimbing akademik. Karena itu penerapan keahlian komunikasi interpersonal menjadi keahlian mendasar yang harus dimiliki oleh para pembimbing akademik. Dengan keahlian komunikasi interpersonal yang memadai pembimbing akademik akan mampu memberikan pengaruh besar kepada konsep diri mahasiswa sehingga terbentuklah konsep diri positif yang akan menunjang keberhasilan belajar dan penerapan nilai-nilai yang diberikan oleh dosen di kelas maupun kegiatan kemahasiswaan yang lain.

\section{DAFTAR PUSTAKA}

Agustiani, Hendriati. Psikologi

Perkembangan, Bandung:Refika Aditama, 2009.

Burn, R.B. Konsep Diri, Teori Pengukuran, Perkembangan dan Perilaku, alih bahasa: Eddy. Jakarta: Arcan, 1993.

Cangara, Hafied. Pengantar Ilmu Komunikasi, edisi revisi; Jakarta: Pt Raja Grafindo Persada, 2011.

\section{Effendy, Onong Uchjana.} Kepemimpinan dan komunikasi,

${ }_{14}$ Roudhonah, IImu Komunikasi,

Jakarta:UIN pres, 2007) cet ke-1 h.54 
NUKHBATUL 'ULUM : Jurnal Bidang Kajian Islam

Vol. 3, No. 1 (2017) : Hal. 34-41

Website: https://journal.stiba.ac.id

ISSN : 2685-7537 (online) 2338-5251 (Printed)

Bandung. CV, Mndar Maju, 1998.

Gunawan, Adi W. Genius Learning Strategy. Jakarta: PT Gramedia Pustaka Utama, 2007.

Liliweri, Alo. Komunikasi Antarpribadi, Cet ke 2. Bandung:Citra Aditya Bakti, 1997.

Roudhonah, Ilmu Komunikasi, Jakarta:UIN pres, 2007.

Soeitoe, Samuel. Psikologi Pendidika. Jakarta : Lembaga Penerbit Fakutas Ekonomi UI, 1982.

Tohirin, Bimbingan dan konseling di Sekolah dan Madrasah Berbasis Integrasi),Jakarta:PT

RAJAGAFINDO PERSADA, 2011..

West, Richard. Turner, Lynn H, Pengantar Teori Komunikasi: Analisis dan Aplikasi. Ed 3., Buku 1.,Jakarta:Penerbit Salemba Humanika. 2007. 